\title{
IMPROVING STUDENT MATHEMATICS LEARNING ACHIEVEMENT THROUGH GROUP INVESTIGATION LEARNING MODELS
}

\author{
Nartini ; SMPN 1 Madiun \\ Darmadi $\triangle$; Universitas PGRI Madiun
}

\begin{abstract}
Although famous as a favorite junior high school, mathematics is st ill a scourge for most students of SMPN 1 Madiun. As a result, students' mathematics learning achievement does not meet the KKM. The group investigation learning model is one alternative to improve student learning achievement. Classroom action research wi th the stages of planning, implementing, observing, and reflecting on each cycle is used to improve this situation. Planning is carried out according to the results of the identification and reflection of the previous cycle. Implementation according to pla n. Observations are emphasized on the implementation of learning, increasing learning achievement, and student responses. Reflections are made to make the necessary improvements so that learning objectives are achieved. The results showed that students hav e positive attitudes and responses to mathematics learning with the group investigation model on the subject of Social Arithmetic. Mathematics learning achievement of students of class VII B of SMP Negeri 1 in 2018/2019 in the subject of Social Arithmetic by using a group investigation model increased with an average value of 81.5 so that it was categorized quite well. Teachers can use the group investigation model as an alternative to improving students' mathematics learning achievement.
\end{abstract}

Keywords: Learning achievement, Learning model, Group investigation.

$\bowtie$ darmadi.mathedu@unipma.ac.id

Citation: Nartini, \& Darmadi. (2020). Improving Student Mathematics Learning Achievement through Group Investigation Learning Models. Social Sciences, Humanities and Education Journal (SHE Journal), 1(2), 35 - 42. DOI: 10.25273/she.v1i2.6625

\section{(cc) BY-NC-SA}

Published by Universitas PGRI Madiun. This work is licensed under the Creative Commons AttributionNonCommercial-ShareAlike 4.0 International License. 


\section{INTRODUCTION}

Submission of material in schools is generally done in a conventional manner. The material is explained by the teacher, while students take notes. Then, the teacher gives exercises to students according to what is in the student book or textbook. Giving assignments is the mainstay of the teacher so students learn. Initial research results at SMPN 1 Madiun show that $10 \%$ of students do homework, $7 \%$ of students do partially incomplete, and $83 \%$ of students do not do at all. Student achievement in SMPN 1 Madiun is low.

The low mathematics learning achievement of SMPN 1 Madiun students was triggered because of the low ability to calculate multiplication and the division of students. Every time there is a multiplication material students always want to count with a calculator that is on a cellphone or other calculator. So is the condition with material that involves division. In two daily tests with a number of questions 10 forms of description with a level of difficulty to easy and with two hours of learning, students still feel less with the results of $50 \%$ students under the minimum completeness criteria (KKM). Students do not feel they have challenges in learning mathematics.

Learning is a conscious effort to gain new knowledge or understanding (resulting in changes in behavior). The atmosphere and learning process need to be conditioned so that students actively develop their potential so that they have religious spiritual strength, self-control, personality, and intelligence. In learning mathematics, students are expected to have selfawareness of the need for knowledge, not be depressed but still be responsible, willing to try and be open to being able, creative and trying to get optimal results. To support this, an appropriate learning model is needed.
The learning model is a conceptual framework that describes a systematic procedure in organizing learning experiences to achieve learning goals (Rusman, 2013).

Expected learning in the 2013 Curriculum is learning that enriches student learning experiences by using a scientific-based approach. The teacher applies various learning models with a scientific-based approach in order to develop three domains of competence, namely knowledge, skills and attitudes as a whole. For this reason, new learning strategies are needed that prioritize and empower students. One strategy that can be used by teachers to activate and develop students' potential in learning mathematics is to apply a group investigative learning model. Through investigation, students can be stimulated to understand the meaning of learning, its benefits, status in learning, and results achieved. Through group work, students can position themselves as productive people, who will be able to meet their daily needs. The teacher provides opportunities for students to measure their learning abilities, apply good learning strategies for students in solving problems in groups. The learning process is directed so that students are able to solve problems systematically and logically with the most effective time possible (Juanda, 2011).

Some research shows the importance of group investigation learning. Mathematical communication skills and students' interpersonal learning after getting group investigation lessons are better than students who get conventional lessons (Nova Fahradina, Bansu I. Ansari, Saiman, 2014). Mathematical communication skills and interpersonal learning students who get group investigative learning are better than students who get conventional learning. 
Multimedia-assisted investigative learning models can increase student learning activities and outcomes in learning bacterial identification material at SMK $\mathrm{N}$ Kalibagor 1 Banyumas Regency (Nina Kholina, Tyas Agung Pribadi, Saiful Ridlo. 2014). The results showed that $\geq$ $80 \%$ of students were active and very active in learning and the completeness of classical learning outcomes for students of Class I AMP and 1 ATP was greater than previous learning which did not apply multimedia-assisted group investigative learning.

The group investigation learning model can improve the mathematical problem solving ability of students of class VIII-4 of SMP Negeri 27 Palembang (Rusdy A. Siroj 2 and Ratu Ilma Indra Putri, 2010). The research took place in two cycles. The first cycle is related to cube and beam material. The results of the first cycle test show that classical learning completeness has only reached $60 \%$. The second cycle relates to prism and pyramid material. The result of the second cycle is that $89 \%$ of students have finished classically. The students' mathematical problem-solving abilities on the subject of constructing the flatsided space of class VIII-4 Palembang 27 State Junior High Schools can be improved through the application of the group investigation learning model.

Maple software-assisted group investigation learning models affect students' mathematical problem solving abilities. One-way variance analysis test with unequal cells concludes that the group investigation learning model is better than the maple group investigation assisted learning model and the two learning models are better than conventional learning models. Against the influence on the mathematical problem solving ability between students in the class applying the maple group investigation assisted learning model, students in the class only apply the group investigation learning model, and students whose class applies the conventional learning model on the subject matter of the matrix (Putri Wulandari1, Mujib2, Fredi Ganda Putra, 2016). [6].

The power and mathematical disposition of High School Students can be developed through group investigation learning (Mumun Syaban. 2009). This study found students' mathematical power and disposition of group investigation approaches well than approach individual investigations. Both are classified as quite good and better than conventional classes. In addition, on mathematical strength and disposition, field dependent students are better than student dependent fields. In addition to these findings, the study found an interaction between teaching approaches and cluster schools on mathematical strength and disposition, and between teaching approaches and cognitive fields on mathematical strength, but there was no interaction between teaching approaches and cognitive fields on mathematical disposition.

The group investigation learning model influences the process skills and science learning outcomes of junior high school students (I Ketut Wiratana, I Wayan Sadia, Ketut Suma., 2013). There were differences in the process skills and science learning outcomes between students who implemented the group investment learning model and students who carried out conventional learning. There is a difference in the process skills between students learning with group investment learning models and students learning conventionally. There are differences in the results of science learning students who carry out learning with group investment learning models with students who carry out learning conventionally.

Learning activities can be increased by group investigation learning in lectures (Siti Masitoh, 2006). The learning process of PLB II research methods through the group investigation learning model for 
students of the PLB FIP Undergraduate program in each cycle receives an increase in learning related to student skills to express ideas in participating in designing teaching materials based on topics / themes discussed in group discussions, discussions class, understanding and applying the concepts of research methods correctly that are shown in critiquing ideas that are put forward in group discussions and class discussions. Student learning activities in the opinion and disturb the opinions of others there was an increase of $2.21 \%$ in census 1 and increased $4.84 \%$ in the second cycle. The performance of students in group discussions during the learning actions of PLB II research methods through the group investigative learning model also increased $1.68 \%$ in the first cycle, and the second cycle increased by $7.48 \%$.

The group investigation model is not just a method of thinking, because students are also taught to optimize the time available to describe, analyze and express an activity that can bridge the current situation with the desired situation. The Group Investigation Model is also a training of character, discipline, responsibility in a team and finally forming an independent spirit so that students have 21st century skills.

The purpose of this study is to find out how the application of the Group Investigation Model can improve mathematics achievement in grade VII students of SMP Negeri 1 Madiun in the 2018-2019 academic year. The benefits provided in this classroom action research are: students can be motivated to optimize time, enjoy learning mathematics in one teamwork and can gain learning experiences. For teachers, this research can be used as input for consideration in appropriate learning research, so as to improve the quality of learning.

\section{METHODS}

This research belongs to the classroom action research (Classroom Action
Research), which was conducted with the aim of improving the quality of learning in the classroom.

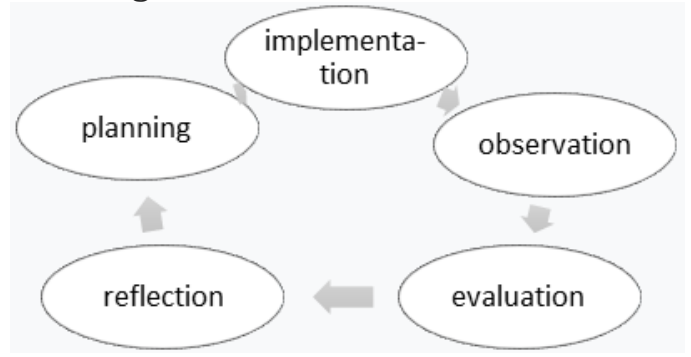

Figure 1. Stages in each PTK cycle

The data collection in this study was carried out in two cycles. Each cycle consists of planning, implementing, observing, evaluating and reflecting.

The place of research is in SMP Negeri 1 Madiun Class VII B in the academic year 2018/2019 which is located at Jalan R.A. Kartini No. 4 Madiun. In this class, previously there had never been any research using the group investigation model. Making a plan of action the study was conducted in the second semester of the $2018 / 2019$ school year, from January to February 2019 during the Mathematics class every day, and every 40 minutes.

The research subjects used in this study were students of class VII B of SMP Negeri 1 Madiun in the academic year 2018 / 2019. The number of students in the class was 32 students. Consisting of 20 female students and 12 male students. The subject has never gotten the subject matter of Social Arithmetic.

Setting in this class action research, the researcher divides the class into several groups. Each group consists of 56 students to facilitate discussion, monitoring, so that it is not crowded, and more focused in peer tutoring.

Data collection methods used in this study are the method of observation, test methods, and questionnaire methods. The observation method was conducted to observe student behavior, implementation of learning, and teacher performance during mathematics learning using the group investigation 
model. The test method is used to measure students' skills, intelligence, abilities or talents. The questionnaire method is used to determine student responses to the implementation and application of the Group Investigation model in mathematics learning.

The instrument used for observation is the observation sheet. Prior to use, the observation sheet is consulted with a mathematics learning expert to provide an assessment, give input if needed, and validation. The focus of observation is the suitability of learning with lesson plans, teaching material, learning time, learning methods, media used, and student learning activities. To find out the percentage of students' attitudes towards Group Investigation learning the following formula is used.

$$
\text { Value }=\frac{\text { student attitude score }}{\text { total number of students }} \times 100 \%
$$

As a collaboration with Dra Rr. Endang Marijani, a mathematics teacher at SMP Negeri 1 Madiun. She is tasked with observing and recording learning activities. Observation data is used as material for reflection.

Pretest and posttest are used for instruments. Pretest serves to find out the initial competencies students have about the learning material used as learning topics. Posttest serves to determine the level of student mastery of competencies that have been determined after learning. To find out the level of completeness of student learning in Group Investigation learning the following formula is used.

Completeness

$$
=\frac{\text { number of complated }}{\text { total number of students }} \times 100 \%
$$

The form of the test used in this study is a matter of essay. The questions were obtained from a number of supporting books so that their validity and reliability had been carried out.

The effectiveness of the group investigation model on individual student achievement, classically using the percentage formula above. This research is said to be successful if the students' grades have met the mastery of learning. The minimum level of mastery assigned to individual learning completeness is $70 \%$ of the units of daily / formative assessment results in each unit of study. The level of mastery learning in mathematics in SMP Negeri 1 Madiun is determined at a minimum score of 70. Mastery learning is that the student has reached the Minimum Mastery Criteria that have been set. As a group, mastery learning is stated to have been achieved in this study if at least $80 \%$ of the number of students meet the minimum completeness criteria.

\section{RESULT AND DISCUSSION}

\section{Implementation of Cycle I}

Cycle I is planned to consist of two learning meetings to discuss sub-points of selling price, purchase price, profit, loss, and calculating profit and loss percentage. Therefore, the researcher prepares RPP, media in the form of shopping receipt, hawker price list, LCD, arranging pretest and posttest questions, also observation sheet to observation.

In the first cycle, the first meeting was held on Tuesday, January 29, 2019 and the second meeting was held on Wednesday, January 30, 2019. All students entered. Learning is carried out in accordance with the lesson plans that have been prepared.

Observations were made on mastery learning, implementation of learning, and student responses. Mastery learning in the observation cycle I is as follows.

\begin{tabular}{|c|c|c|c|c|c|}
\hline \multirow{2}{*}{ Value } & \multicolumn{2}{|c|}{ Students } & \multicolumn{2}{|c|}{ Percentage } & \multirow{2}{*}{ Information } \\
\hline & Pretest & Postest & Pretest & Postest & \\
\hline$<70$ & 27 & 15 & 84 & 47 & Not Complete \\
\hline$\geq 70$ & 5 & 17 & 16 & 53 & Complete \\
\hline Total & 32 & 32 & 100 & 100 & \\
\hline
\end{tabular}
Table 1. Completeness of Students in Cycle I

The frequency of students who score more than or equal to 70 is 17 students, this shows that $53 \%$ of the total students have reached the specified KKM. Students who score less than 70 
are as many as 15 students, this shows that $47 \%$ of the total number of students have not reached the specified KKM. The average value of student achievement in posttest 70.8 . While the average pretest score is 54.1. In this case an increase in value of 16.7. The results of observations of the implementation of learning in cycle 1 are students in working on worksheets that are still not confident, tend to lean on their peers, some children still tend to be confused with the work to be done, and there are some students who try to ask questions. By observing the results of observations in the first cycle, the researchers reflect. Researchers found weaknesses in the first cycle as follows: Students are still not familiar with the group investigation model so that students are less active in carrying out learning activities. Researchers do not master the class so there are still some students who are still busy. Students still feel doubt in the process.

\section{Implementation of Cycle II}

In cycle II, the researcher prepares a learning plan to discuss gross, net, tare, single interest, tax, discount, and installment sub-topics. For this reason, students are asked to bring several packs of snacks, pictures of clothes with discounts, VAT shopping receipts, and scales.

The teacher as a researcher prepares lesson plans and observation sheets, question sheets for pretest and posttest. The first cycle II meeting was held on Tuesday 12 February 2019 and was attended by 32 students. The second meeting on Wednesday, February 13, 2019 was attended by 32 students. For each learning meeting held in accordance with the lesson plans that have been prepared. In the observation cycle II obtained mathematical learning completeness data in the post test as follows.
Table 2. Completeness of Students in Cycle II

\begin{tabular}{|c|c|c|c|c|c|}
\hline \multirow{2}{*}{ Value } & \multicolumn{2}{|c|}{ Students } & \multicolumn{2}{|c|}{ Percentage } & \multirow{2}{*}{ Information } \\
\hline & Pretest & Postest & Pretest & Postest & \\
\hline$<70$ & 9 & 6 & 28 & 19 & Not Complete \\
\hline$\geq 70$ & 23 & 26 & 72 & 81 & Complete \\
\hline Total & \multicolumn{2}{|r|}{32} & \multicolumn{2}{|c|}{100} & \\
\hline
\end{tabular}

Students who scoreless or below KKM are 6 students or $19 \%$ of 32 students. Students who scored more or equal to KKM were 26 students or in the percentage of students who completed $81 \%$ of 32 students. c. The average value of pretest student learning achievement gets 77.4 while the posttest gets 81.5 . In this case an average score of 4.1 increased. d. Learning is carried out in accordance with the lesson plans that have been prepared. From observation the learning goes according to the scenario. Students begin to get enthusiastic. Already starting to look independent, forward to the class in the presentation began to dare. Some students began to appear asking questions, actively answering in the discussion.

Based on observations and evaluations in the second cycle, the achievement of completeness has exceeded $80 \%$, precisely $81.25 \%$, then according to the indicators of success in this study the research is said to have been achieved.

\section{Improved Student Completeness}

Improved student learning completeness learning outcomes from cycle I to cycle II can be seen in the following table.

Table 3. Improved Student Learning 


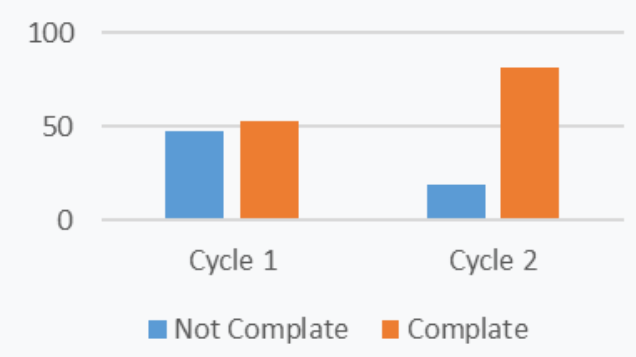

The data shows an increase in student learning completeness after using a group investigation learning model. These results are in accordance with the results of research by I Ketut Wiratana, I Wayan Sadia, and Ketut Suma (2013) that the group investigation learning model influences the process skills and student learning outcomes of science. Improved students' learning completeness occurs because the group investigation model is not just a method of thinking, but students are also taught to optimize the time available to describe, analyze and express an activity that can bridge between the current situation and the desired situation. Improved Student Response Improved student responses regarding the effectiveness of the group investigation model during learning can be seen based on the results of the student response questionnaire. Researchers used a questionnaire questionnaire in the form of a KBM check list, which was filled in by class VIIB students with a total of 32 students. The questionnaire given by students was 10 questions with three options.

The data shows that $84.4 \%$ of the number of students sometimes have difficulty in mathematics. Most students assume that mathematics is full of formulas. But among 32 students who filled out the questionnaire, 27 students agreed to hold pretest and posttest. More than $81.3 \%$ of students prefer to study mathematics with peers and with a long time, and not immediately assessed, it is likely because the burden of getting grades makes students have to target to study harder. Students are encouraged to understand in order to easily learn the next material as many as 24 students, and 22 of 32 students begin to multiply the practice questions. This means that students have a strong desire to be able to solve math problems.

It was also seen that more than half of all students disliked the group Investigation model, because this method demands that they teach their friends who lack knowledge of the material, and they fear that their final grades will be rivaled by the friends they teach. Competence in class VIIB is pretty good in value competition. But the Group Investigation Model can motivate students to understand, understand, even though it takes a long time with the peer group they choose and gives an opportunity to express opinions in the group. Because it seemed that he did not like the group Investigation model of only 2 students, 18 other students were skeptical about the concerns of the value competition. Thus the effectiveness of the group investigation model in mathematics learning can be said to be successful. Both students and teachers support the application of the group investigation model. The Group Investigation Model also trains character, discipline, is responsible in a team and finally forms an independent spirit so that students have 21st century skills.

\section{CONCLUSION}

Students have positive attitudes and responses towards mathematics learning with the group investigation model on the subject of Social Arithmetic. Mathematics learning achievement of students of class VII B of SMP Negeri 1 in 2018/2019 in the subject of Social Arithmetic using the group investigation model increased with an average value of 81.5 so that it was categorized quite well.

Based on the conclusions above, the authors advise as follows: In implementing the learning process it is expected to apply the group 
investigation model as one way to improve student achievement, especially for social arithmetic material and it is possible to do it on another subject. It is better for students to be told what things must be done to be completed in mastering the material. Researchers who will conduct similar studies, should optimize time control to be as effective as possible so that learning objectives are achieved on target. Students are constantly motivated to study hard independently and are ready to become peer tutors. Students also need to be given insight into the importance of collaboration in groups to achieve goals, while still having responsibilities as a healthy personal and social self. Students to always be active and increase participation in mathematics learning activities, especially group activities so that mastery of the material can be achieved in order to get the desired learning achievement.

\section{REFERENCES}

Rusman. (2013). Learning Models. Jakarta: Rajawali Press.

Juanda. (2011). Teaching Model Group Investigation in Teaching Structure. Journal of Literature Vol. 6 No. 1

Nova Fahradina, Bansu, Ansari, Saiman. (2014). Improving Mathematical Communication Skills and Learning Independence of Junior High School Students by Using a Group Investigation Model. Journal of Mathematical Didactics. ISSN: 2355-4185. Vol. 1, No. 1, September 2014. P. 54 - 64

Nina Kholinah, Tyas Agung Pribadi, Saiful Ridlo. (2014). Application of Multimedia Assisted Group Investigations on Bacteria Identification Materials. Wednesday, July 16, 2014. Journals of Biology. Department of Biology, FMIPA Semarang State University, Indonesia Building D6
Lt.1 Jl Raya Sekaran Gunungpati Semarang Indonesia 50229

Lela Anggraini, Rusdy A. Siroj, and Ratu Ilma Indra Putri. (2010). Application of the Group Investigative Learning Model to Improve the Mathematical Problem Solving Ability of Class VIII-4 Students at SMP Negeri 27 Palembang. Journal of Mathematics Education, Volume 4. No.1, June 2010. p. 34-43

Putri Wulandari, Mujib, Fredi Ganda Putra. (2016). Effect of Maple Software Assisted Group Investigation Learning Model on Mathematical Problem Solving Ability. Al-Jabar: Journal of Mathematics Education Vol. 7, No. 1, 2016, pp. 101-106

Mumun Syaban. (2009). Developing Power and Mathematical Disposition of High School Students Through Investigative Learning. Educationist Vol. III No. July 2, 2009. ISSN: 1907 - 8838. P. $129-136$

I Ketut Wiratana, I Wayan Sadia, Ketut Suma. (2013). The Effect of Cooperative Learning Models on Group Investigation on the Process Skills and Learning Outcomes of Junior High School Students. e-Journal of Ganesha University Education Postgraduate Program. Natural Sciences Study Program. (Volume 3 of 2013). P. $1-12$

Siti Masitoh (2006). Increased Learning Activities with Group Investigation Learning in Lectures PLB II research methods. Journal of Educational Sciences, Volume 13 , Number 2, June 2006, p. 100107 